\title{
Nutritive Value of the Carcass of African Catfish (Clarias gariepinus Burchell, 1822) Fingerlings fed at Different Frequencies
}

\author{
Laurat, T., Maimunatu, A. and Vandi, P. \\ Department of Zoology, Modibbo Adama University of Technology, Yola, Nigeria
}

\begin{abstract}
The experiment on African catfish Clarias gariepinus fingerlings $3.55 \pm 0.01 \mathrm{~g}$ average weight and $4.09 \pm 0.05 \mathrm{~cm}$ average length, was to know the effect of feeding frequencies on the nutritive value on the carcass, the were fed with commercial feed (Coppens) of 58\% crude protein level at 5\% body weight, once (at 11:00 $\mathrm{am}$ ), twice (9:00am and 4:00pm), thrice (9:00am, 1:00pm and 4:00pm), and four times (9:00am, 11:00am, 1:00pm and 4:00pm), daily to satiation for 14 weeks. The Mean Feed Consumption show that Treatment D had the highest total feed consumption of $54.10 \mathrm{~g}$, while the lowest feed consumption value of $43.20 \mathrm{~g}$ was noted Treatment A which was the fish fed once per day. The mean proximate composition of the fish carcass show that crude protein was highest in Treatment D with $62.78 \pm 0.22$, while Treatment $A$ had the least with $54.72 \pm 0.02$. Moisture content show that Treatment $C$ had the highest with 11.86 \pm 0.14 , while Treatment $A$ had the least with 7.80 \pm 0.01 . Ash content show that Treatment A had the highest with $6.90 \pm 0.22$, while Treatment $D$ had $1.08 \pm 0.63$, which was the least. Crude lipid show that Treatment $B$ had the highest with 11.78 \pm 0.17 , while Treatment $C$ had the least, with $9.24 \pm 0.33$. The study suggests that body the composition of African catfish fingerlings is affected by the frequency of feeding.The results on feed utilization suggests that $C$. gariepinus fingerlings should be fed at four times per day for maximum growth and better survival.
\end{abstract}

Keywords: Feeding Frequency, Nutritive Value, Feed Utilization, African Catfish.

\section{Introduction}

Fish is a relatively cheap source of animal protein and other essential nutrient required in human diet [1] it may be the sole accessible and/or affordable source of animal protein for poor households in urban areas. The nutritive value of fish feed depends largely on the quality of protein of the ingredients used in the formulation of feed [2]. The nutritional value of fish flesh comprises of moisture, dry matter, protein, lipids, vitamins, minerals and caloric value of the fish [3] and this is the major reason why fish is a favourite food for the entire society [4]. [5] reported that fish is acceptable because of its high palatability, low cholesterol and tender flesh. Fish flesh contains significantly low lipids and higher water than beef or chicken and is favoured over other white or red meat. Marine fish are source of high quality protein, vitamins and essentials minerals and a rich source ofomega-3 long chain poly unsaturated fatty acid [6]. These fats are important for maintaining the integrity of members of all living cells, for making prostaglandins which regulate many body processes such as inflammation and body clotting [7].

Fish meat is generally a good source of vitamin B and, in the case of fatty species of A and D vitamins. As for minerals, fish is a particularly valuable source of calcium and phosphorus as well as iron, copper and selenium. In fish processing, the knowledge of proximate composition i.e. the analysis of moisture, ash, protein and fat content of fish is very important as the information on lipid, proteins, ash, moisture content is needed for effective utilization. Proximate composition of food is of growing interest to consumers because of the effect of the various levels of protein, lipids, water and ash have on the storage and texture of fish, [8]. Several authors have reported that most fish species are highly sensitive to dietary inadequacy of vitamin C. deficiencies in fish can cause reduced growth rate, deformation of skeletal and cartilaginous tissues, slow wound repairs, increased mortality rate, abnormal pigmentation [9]. Besides being used as food, fish is also in increasing demand for use as livestock feed. However, information on the chemical composition of fishes is valuable to nutritionists that are concerned with the available sources of low fat, high protein foods such as marine fishes [8]

It is of biological importance to study the distribution of mineral element present in living organism since many of these elements take part in some metabolic processes and are to be indispensable to all living things [10]. [11] reported that a reduction in lipid content of fish could be seen as beneficial from a processor's point of view because of the associated reduction in the development of rancid flavours Fish nutrition is critical in fish farming because feed represents $40-50 \%$ of production cost [12]. Fish feed account for at least $60 \%$ of the total cost of production [13]. Fish also contains significant amount of essential amino acids, particularly lysine in high concentration which is low in cereal. Fish protein can therefore be used to complement the amino acid pattern and the overall protein quality of a mixed diet [14]. 
In fish processing, the knowledge of proximate composition i.e. the analysis of moisture, ash, protein and fat content of fish is very important as the information on lipid, proteins, ash, moisture content is needed for effective utilization. Proximate composition of food is of growing interest to consumers because of the effect of the various levels of protein, lipids, water and ash have on the storage and texture of fish. Besides being used as food, fish is also in increasing demand for use as livestock feed. [15]. It has been found that some animals are able to synthesize certain vitamins in their bodies in quantities sufficient to meet their metabolic needs; these vitamins do not have to be provided in their diets [16]. However, some fish species cannot synthesis vitamin $\mathrm{C}$ in their bodies due to lack of gulonolactone oxidase and this enzyme is required for biosynthesis of ascorbic acid from glucose or other simple precursors [17][18], therefore, it must be provided in their diets. Over the years, the ascorbic acid requirements of some commercial important fish species have been reported [19]. The proximate composition of intensively farmed fish is an integral part of evaluating their nutritional status. However, the diet composition, metabolic adaptation and variation in fish activity are the main factors responsible for the change in nutritional composition of fish [20]. Thus, analysis of nutrients is an important factors that could be considered in fish feed assessment. This study then evaluates proximate composition of African catfish (Clarias gariepinus) fed at different frequencies.

\section{Materials and Methods}

Study Area: The study was conducted in the Laboratory of the Department of Zoology, Modibbo Adama University of Technology, Yola, Adamawa State, Nigeria. A total of 180 Clarias gariepinus fingerlings $3.55 \pm 0.01 \mathrm{~g}$ average weight and $4.09 \pm 0.05 \mathrm{~cm}$ average length were obtained from a fish farm in Yola, Nigeria. Fish were kept in plastic tanks for acclimatization at experimental conditions for seven days before commencement of feeding trials and were fed a maintenance diet of $1.5 \mathrm{~mm}$ size commercial feed (Coppens) containing 58\% crude protein. The fingerlings were divided equally into twelve (12) 20L plastic tanks: 12 fish held in each tank. The tanks were fitted to a semi flow through system. Trial conditions included four feeding frequencies, with each feeding frequency being experimentally tested in triplicate. The experiment was laid out in a completely randomized block design with 12 fishes stocked in each plastic tank of 20L capacity. The experiment was conducted over a period of 14 weeks. The treatment was designated A, B, C and D to represent once, twice, thrice and four times feeding frequencies respectively.

\section{Feeding}

Fish were fed commercial feed (Coppens) of 58\% crude protein level at 5\% body weight. Feeding trial included once (at 11:00 am), twice (9:00am and 4:00pm), thrice (9:00am, 1:00pm and 4:00pm), and four times (9:00am, 11:00am, 1:00pm and 4:00pm), daily to satiation for 14 weeks.

Fish Length-Weight Measurement

The initial body weight of each set of fish was measured using sensitive weighing balance before stocking and subsequently bulk weighing of the fish in each tank was done at two weeks interval. The length measurement was carried out to the nearest centimeters using a measuring board graduated in centimeters. Total length was measured from the anterior most extremity of the fish to the end of the caudal fin. The total weight was measured in grams using Ohaus electric weighing balance of 500 capacity.

\section{Survival and Mortality}

The survival and mortality of fish in each treatment were monitored by counting the mortalities on a daily basis Analysis of Fish Growth and Nutrient Utilization

Mean Weight Gain (MWG)

The fish mean weight gain (MWG) was calculated as the difference between the final mean weight of the fish and initial mean weight in grams [21].

Specific Growth Rate (SGR)

This is the mean percentage increase in body weight per day over a given time interval [22]. In this study the time interval was 14 weeks.

$\mathrm{SGR}=\underline{\text { Ln weight at the time of observation }- \text { Ln initial weight }} \times 100$

Duration of experiment in days

Where $\mathrm{Ln}=$ natural $\log$

Relative Growth Rate (RGR)

This is the percentage ratio of the weight gained to the initial body weight which will be determined according to [23] as follows:

Feed Conversion Ratio (FCR)

$$
\operatorname{RGR}(\%)=\left(\frac{\left.\mathrm{W}_{\mathrm{f}}-\mathrm{W}_{\mathrm{i}}\right)}{\mathrm{W}_{\mathrm{i}}} \times 100\right.
$$


The efficiency of a feed is normally measured by the amount necessary to produce a unit weight of fish. This is called the feed conversion ratio [24].

$\mathrm{FCR}=$ Total dry feed consumed $(\mathrm{g})$

Total Wet weight gain $(\mathrm{g})$

Protein Intake (PI)

This is the numerical value of the quantity of protein present in the feed fed to the fish during the experimental periods and was determined following [25]method as follows:

PI ( $\mathrm{g}$ of protein in $100 \mathrm{~g}$ diet/fish $)=$ Total feed intake $\mathrm{x} \%$ crude protein in the diet.

Protein Efficiency Ratio (PER)

This is the efficiency with which the fish utilizes dietary protein and is defined by the equation: [26].

$\mathrm{PER}=\underline{\text { wet weight gain by fish }(\mathrm{g})}$

Weight of crude protein fed

Net Protein Utilization (NPU)

NPU denotes the protein retention in the body of the fish. This was calculated as follows:

$\mathrm{NPU}=\underline{\mathrm{CP}}_{\frac{\mathrm{f}-}{\mathrm{PI}}}$

Where: $\mathrm{CP}_{\mathrm{i}}=$ Crude Protein in fish at the beginning of the experiment

$\mathrm{CPf}=$ Protein in fish at the end of the experiment

$\mathrm{PI}=$ Protein intake $(\mathrm{g}$ of protein in $100 \mathrm{~g}$ of diet/fish)

\section{Result}

The Mean Feed Consumption for the study period show that Treatment D had the highest total feed consumption of $54.10 \mathrm{~g}$, followed by Treatment $\mathrm{C}$ with $48.95 \mathrm{~g}$, Treatment B had $45.54 \mathrm{~g}$ while the lowest feed consumption value of $43.20 \mathrm{~g}$ was noted Treatment $\mathrm{A}$ which was the fish fed once per day. (Table 1) The mean proximate composition of the fish carcass show that crude protein was highest in Treatment D with $62.78 \pm 0.22$, followed by Treatment $C$ with 58.24 \pm 0.11 , Treatment B had 55.12 \pm 0.05 , while Treatment A had the least with $54.72 \pm 0.02$. Moisture content show that Treatment $C$ had the highest with $11.86 \pm 0.14$, followed by Treatment $B$ with $8.36 \pm 0.19$, Treatment D had 8.21 \pm 0.00 , while Treatment $\mathrm{A}$ had the least with $7.80 \pm 0.01$. As for crude fibre; Treatment A had the highest with $1.89 \pm 0.04$, followed by Treatment B with $1.17 \pm 0.04$, Treatment $\mathrm{C}$ had $1.10 \pm 0.15$, while Treatment D had 1.08 \pm 0.63 , which was the least. Ash content show that Treatment A had the highest with $6.90 \pm 0.22$, followed by Treatment B with $6.96 \pm 0.55$, Treatment $C$ had $5.62 \pm 0.50 \mathrm{n}$ while the least was 5.25 \pm 0.24 in Treatment D. crude lipid show that Treatment B had the highest with $11.78 \pm 0.17$, followed by Treatment A with 10.34 \pm 0.11 , Treatment $\mathrm{D}$ recorded $9.31 \pm 0.25$, while Treatment $\mathrm{C}$ had the least, with 9.24 \pm 0.33 . the Nitrogen Free Extract (NFE) show that Treatment A had the highest with $18.35 \pm 0.22$, followed by Treatment B with $16.61 \pm 0.18$, and Treatment $\mathrm{C}$ with $13.94 \pm 0.58$, while Treatment $\mathrm{D}$ had the least with 13.37 \pm 0.69 (Table 2). The Feed Conversion Ratio (FCR) show that Treatment B had the highest with 0.54 , followed by Treatment $\mathrm{C}$ with 0.52 , Treatment $\mathrm{D}$ had 0.51 The least was Treatment A with 0.44 . A summary of the growth and feed utilization of different feeding frequency is shown in (Table 3 ).

Table 3.Table 1: Mean Total Feed Consumption Per Fish at Each Feeding Frequency During The Study Period

\begin{tabular}{|l|l|l|l|l|l|l|l|l|l|l|}
\hline Feeding Frequency & Week 0 & Week 2 & Week 4 & Week 6 & Week 8 & Week 10 & Week 12 & Week 14 & $\begin{array}{l}\text { Total Feed } \\
\text { Intake (g) }\end{array}$ & $\begin{array}{l}\text { Mean Feed } \\
\text { Intake (g) }\end{array}$ \\
\hline $\mathrm{A}$ (Once) & 5.00 & 5.40 & 5.60 & 5.40 & 5.70 & 5.50 & 5.30 & 5.30 & 43.20 & 3.09 \\
\hline $\mathrm{B}$ (Twice) & 5.60 & 5.63 & 5.66 & 5.80 & 5.73 & 5.70 & 5.73 & 5.69 & 45.54 & 3.25 \\
\hline $\mathrm{C}$ (Thrice) & 6.00 & 6.13 & 6.16 & 6.28 & 6.03 & 6.10 & 6.10 & 6.15 & 48.95 & 3.50 \\
\hline $\mathrm{D}$ (Four times) & 6.25 & 6.65 & 6.85 & 7.06 & 7.04 & 6.85 & 6.65 & 6.75 & 54.10 & 3.86 \\
\hline
\end{tabular}

Table 2: Mean Proximate Composition of Fish Carcass at Different Feeding Frequency (\%)

\begin{tabular}{|l|l|l|l|l|l|l|}
\hline Treatment & Crude Protein & Moisture & Crude Fibre & Ash & Crude Lipid & $\begin{array}{l}\text { Nitrogen } \\
\text { Extract (NFE) }\end{array}$ \\
\hline A. Once & $54.72 \pm 0.02$ & $7.80 \pm 0.01$ & $1.89 \pm 0.04$ & $6.90 \pm 0.22$ & $10.34 \pm 0.11$ & $18.35 \pm 0.22$ \\
\hline B. Twice & $55.12 \pm 0.05$ & $8.36 \pm 0.19$ & $1.17 \pm 0.04$ & $6.96 \pm 0.55$ & $11.78 \pm 0.17$ & $16.61 \pm 0.18$ \\
\hline C. Thrice & $58.24 \pm 0.11$ & $11.86 \pm 0.14$ & $1.10 \pm 0.15$ & $5.62 \pm 0.50$ & $9.24 \pm 0.33$ & $13.94 \pm 0.58$ \\
\hline D.Four times & $62.78 \pm 0.22$ & $8.21 \pm 0.00$ & $1.08 \pm 0.63$ & $5.25 \pm 0.24$ & $9.31 \pm 0.25$ & $13.37 \pm 0.69$ \\
\hline Initial Fish & $54.15 \pm 0.05$ & $9.00 \pm 0.13$ & $1.90 \pm 0.20$ & $5.98 \pm 0.00$ & $10.11 \pm 0.11$ & $18.86 \pm 0.02$ \\
\hline
\end{tabular}

\pm shows the standard error of mean (SEM) of the proximate composition 
Table 3: Summary Table Showing Growth and Feed Utilization of Different Feeding Frequency of Coppens Diet by Clarias gariepinus

\begin{tabular}{|l|l|l|l|l|l|}
\hline Parameters & $\begin{array}{l}\text { A } \\
\text { Once }\end{array}$ & $\begin{array}{l}\text { B } \\
\text { Twice }\end{array}$ & $\begin{array}{l}\text { C } \\
\text { Thrice }\end{array}$ & $\begin{array}{l}\text { D } \\
\text { Four times }\end{array}$ & SEM \\
\hline Initial mean weight (g) & 3.55 & 3.57 & 4.00 & 3.58 & \pm 0.07 \\
\hline Final mean weight (g) & 22.66 & 28.01 & 29.36 & 30.98 & \pm 0.20 \\
\hline Mean weight gain (g) & $19.11^{\mathrm{a}}$ & $24.44^{\mathrm{b}}$ & $25.36^{\mathrm{c}}$ & $27.40^{\mathrm{d}}$ & \pm 0.8 \\
\hline Initial mean length (mm) & 4.09 & 4.11 & 4.20 & 4.15 & \pm 0.05 \\
\hline Final mean length (mm) & 10.44 & 12.81 & 13.32 & 13.39 & \pm 0.04 \\
\hline Mean length gain (mm) & 6.35 & 8.70 & 9.12 & 9.24 & \pm 0.03 \\
\hline Relative growth rate (RGR) (\%) & $538.31^{\mathrm{a}}$ & $684.59^{\mathrm{b}}$ & $634.00^{\mathrm{c}}$ & $765.36^{\mathrm{d}}$ & \pm 0.02 \\
\hline SGR (\%) & 0.82 & 0.91 & 0.88 & 0.96 & \pm 0.03 \\
\hline Mean feed intake (g) & $3.09^{\mathrm{a}}$ & $3.25^{\mathrm{a}}$ & $3.50^{\mathrm{b}}$ & $3.86^{\mathrm{c}}$ & \pm 0.12 \\
\hline Feed conversion ratio (FCR) & 0.44 & 0.54 & 0.52 & 0.51 & \pm 0.12 \\
\hline Condition factor (K) & 7.46 & 3.71 & 3.34 & 0.20 & \pm 0.99 \\
\hline Protein intake & $0.95^{\mathrm{a}}$ & $1.14^{\mathrm{b}}$ & $1.37^{\mathrm{c}}$ & $1.77^{\mathrm{d}}$ & \pm 0.04 \\
\hline Protein efficiency ratio (PER) & 34.75 & 44.34 & 44.53 & 44.64 & \pm 0.01 \\
\hline Net Protein Utilization (NPU) & 60.00 & 85.09 & 298.54 & 487.57 & \pm 0.30 \\
\hline Survival (\%) & 40 & 80 & 60 & 81.5 & \pm 0.01 \\
\hline
\end{tabular}

Mean with different superscript are significantly different from each other while the same superscript indicate that they are not significantly different from each other at $\mathrm{p}<0.05$.

\section{Discussion}

The Food Conversion Ratio (FCR), show that those fed once and four times daily had low FCR, while the group fed twice daily had the highest FCR, this is different from the report of [27], who reported that low FCR values were recorded in African catfish fed with twice every other day followed by once a day and twice/day respectively whereas significantly no difference in FCR values observed in fingerlings fed with all the feedings regimes except once every other day fed groups. This indicates that the efficiency of feed utilization and feed conversion was not influenced by the feed frequency. This might indicate that African catfish fed more frequently might utilize diet less efficiently than fish fed less frequently. Also, [28], reported too in channel catfish fed once/day or twice/day had similar FCR values. [29], found that there was no difference in FCR among hybrid sunfish fed one, two, three, or four times /day. While, [30] stated that feeding frequency had little effect on FCR. This may indicate that food consumption is the growth limiting factor. As found for other fish species [31] [32], the greater the feed intake, the greater the growth response. This was the expected result since a higher amount of nutrients become available to the fish when they are fed more often.

High lipid content was recorded in those fed twice daily than those fed once, thrice and four times daily, protein content show that those fed four times daily had the highest than those fed once, twice and thrice daily, this is different from the report of [27] who recorded that African catfish fed once a day and once every other day had less lipid content than fish fed twice/day and twice every other day. [33] reported increased lipid levels in channel catfish fed twice daily compared to fish fed once daily. [28] reported, no significant differences in percentage moisture, protein, and lipid in fillet of channel catfish fed either once or twice daily. It has been demonstrated that, low body lipid content of fish resulted from declined feeding frequency [34]. [35] reported that body composition was not influenced when Atlantic salmon were fed once a day.

\section{Conclusion}

This study suggests that the nutritive value of African catfish fingerlings is affected by the frequency of feeding. The results of this study based on the feed conversion and feed utilization suggests that $C$. gariepinus fingerlings $(3.55 \pm 0.01 \mathrm{~g}$ average weight and $4.09 \pm 0.05 \mathrm{~cm}$ average length) should be fed at four times per day for maximum growth and better survival.

\section{References}

[1]. Fawole, O. O., Ogundiran, M. A., Ayandiran, T. A. and Olagunju, O. F. Mineral Composition in some selected fresh water fishes in Nigeria, African Journal for food safety 9: 200752-58.

[2]. Hu, L., Yun, B., Xue, M., Wang, J., Wu, X., Zheng, Y. and Han, F. Effects of fishmeal quality and fishmeal substitution by animal protein blend on growth performance, flesh quality and liver histology of Japanese seabass (Lateolabrax japonicas). Aquaculture, 5 : 2013, 372-375.

[3]. Steften, W. Fresh water fish wholesome foodstuff. Journal of Agricultural Science, 6, 2006,320-328.

[4]. Ojewole, G. S. and Ammah, S. I. Nutritive and economic value of Danish Fish meal, crayfish, dustmeal and shrimp waste meal, inclusion in broiler diet, International Journal of science, 5: 2006, 390-394,

[5]. Eyo, A. A. Fish processing Technology in the tropics, University of Ilorin, Nigeria 430 pp. 2000

[6]. Dahi, I. J., Bjorkkjar, I. E., Graft-Makia, M. K. and Idemensten, B. Fish more than just Omega 3. T.dsskr Nor laegeforen, 126: 2006, 309-311.

[7]. Conor, W. E. Important of N.3 Fatty Acid in Health and Disease. American Journal of Clinical Nutrition, 71: 2008, 1715-1755.

[8]. Foran, J. A., Carpenter D. O., Hamilton M. C., Knuth B. A., and Schwager S. J. Rusk based consumption advice for Farmed Atlantic and dioxin - like composition, Emmon health perspective 33: 2005, 552-556. 
[9]. Xie, Z. and Niu, C. Dietary ascorbic acid requirement of juvenile ayu (Plecoglossus altivelis). Aquaculture Nutrition, 12: 2006, 151156.

[10]. Shulman, G. E. Life cycle of fish, physiology and biochemistry. Haisted press. A division of John Wiley and Sons Inc. 1st edition, 101-104. 1974

[11]. Balogun, A. M. and Talabi, S. O. Proximate Analysis of the flesh and anatomical weight composition of Tuna. Journal of Food Chemistry, 17: 1985, 117-123.

[12]. Craig S, and Helfrish L. A. Understanding Fish Nutrition, Feeds and Feeding. Department of Fisheries and Wild Life Sciences, Virginia Tech., pp. 420-456. 2002

[13]. Gabriel, U. O., Akinrotimi, O. A., Ananwu, P. E., Bekibele, D. O. and Onunkwo, D. N. Locally produced fish feed potential for aquaculture development in sub-Saharan Africa. Journal of Agriculture Research, 2: 2007, 287-295.

[14]. FAO United Nations Food and Agricultural Organization. Responsible Fish Trade and Food Security, Journal of Environmental Agricultural and Food Chemistry, 456: 2005, 6.

[15]. Odedeyi, D. O. Nutritive Values of The Carcass Of African Catfish (Clarias gariepinus) Fingerlings Fed Raw And Steam-Heated Moringa Oleifera Diets. International Conference on Advances in Environment, Agriculture \& Medical Sciences (ICAEAM'14) November 16-17, Kuala Lumpur (Malaysia) 2014

[16]. Robinson, E. H. and Li, M. H. Channel Catfish Ictalurus puntatus in C.D. Webster, ed. Nutrient requirement and feeding of finfish for aquaculture, Willingford. CABI Publishing, CABI International, 293-318. 2003

[17]. Dabrowski, K. History, Present and Future of Ascorbic Acid Research in Aquatic Organism. In: Ascorbic and in Aquatic Organisms: Status and Perspectives, Dabrowski, K. (Ed.). CRC Press, Boca Raton, 225-277. 2001

[18]. O'keefe, T. Ascorbic acid and stable ascorbate esters as sources of vitamin C in aquaculture feeds. ASA Tech. Bull., 48: 2001, 1-10.

[19]. Halver, J. E. The Vitamins. In: Fish Nutrition, Halver, J.E. and R.W. Hardy (Eds.), 3rd Edn. Academic Press, San Diego, CA. pp824, 2002

[20]. Rehulka, J. Haematological and biochemical analysis in rainbow trout, Oncorhynchus mykiss affected by Viral Haemerrhagic Septicaemia (VHS). Distribution of Aquatic Organism, 56: 2003, 186-193.

[21]. Castell, J. D. and Teiwa, K. Report of the EIFAC, IUNS and ICES working group on standardization of methodology in Fish Nutrition Research FIPAC/736, EIFAC/FAO. The State of World: Fishery and Agriculture. FAO Fisheries technical Paper No. 500. Rome, 1980.

[22]. Brown, M. E. Experimental Studies on growth. In: Physiology of Fishes. Vol.1 (M.E. Brown ed). Academy Press. New York. 1957

[23]. Fasakin, E. A., Balogun, A. M. and Fagbenro, O. A. Evaluation of sun dried water fern Azolla africana and duckweed, Spirodella polyrrhiza, in practical diets for Nile Tilapia, Oreochromis niloticus fingerlings. Journal of Applied Aquaculture, 11 (4): 2001, 8392.

[24]. Hepher, B. Nutrition of Pond fishes. Cambridge University press, U.K 388pp. 1988

[25]. Sveier, H., Raae, A. J. and Lied, E. Growth and protein turnover in Atlantic salmon (Samo salar L.); the effect of dietary protein level and protein particle size. Aquaculture, 185: 2000, 101-120

[26]. Osborne, T. B., Wendel, L. B. and Ferry, E. L. A method for expressing numerically the growth-promoting value of proteins. Journal of Biochemistry, 39: 1919, 223-224.

[27]. Marimuthu, K., Ang-Chi, C., Muralikrishnan, S. and Kumar, D. Effect of Different Feeding Frequency on the Growth and Survival of African Catfish (Clarias Gariepinus) Fingerlings. Advances in Environmental Biology, 4(2): 2010, $187-193$.

[28]. Webster, C. D., Tidwell, J. H. and Yancey, D. H. Effect of protein level and feeding frequency on growth and body composition of cage-reared channel catfish. Progressive Fish Culturist, 54: 1992, 92-96.

[29]. Wang, N., Hayward, R. S. and Noltie, D. B. Effect of Feeding Frequency on Food Consumption, Growth, Size Variation, and Feeding Pattern of Age-0 Hybrid Sunfish. Aquaculture, 165: 1998, 261-267.

[30]. Hogendoorn, H. Controlled propagation of the African catfish, Clarias lazera (CandV), 111. Feeding and growth of fry. Aquaculture, 21: 1980, 233-241.

[31]. Lee, S. M., Cho, S. H. and Kim, D. J. Effects of Feeding Frequency and Dietary Energy Level on Growth and Body Composition of Juvenile flounder, Paralichthys olivaceus Temminck and Schlegel. Aquaculture Research, 31: 2000, 917-921.

[32]. Fatan, N. A., Hashim, R., Chong, A. S. C. and Ali, A. Enhancement of monosex hybrid red tilapia, Oreochromis mossambicus X O. niloticus, production in portable canvas tanks through mixed feeding strategies. Journal of Applied Aquaculture, 17(4): 2005, 99111 .

[33]. Noeske-Hallin, T. A., Spieler, R. E., Parker, N. C. and Suttle, M. A. Feeding time differentially affects fattening and growth of channel catfish. Journal of Nutrition, 115: 1985, 1228-1232.

[34]. Kayano, Y., Yao, S., Yamamoto, S. and Nakagawa, H. Effects of feeding frequency on the growth and body constituents of young redspotted grouper, Epinephelus akaara. Aquaculture, 110: 1993, 271-278.

[35]. Sveier, H. and Lied, E. The Effect of feeding regime on growth, feed utilization and weight disposition in large Atlantic salmon (Salmo salar) reared in seawater. Aquaculture, 165: 1998, 333345. 